\title{
Pseudoalteromonas antarctica sp. nov., Isolated from an Antarctic Coastal Environment
}

\author{
N. BOZAL, ${ }^{1}$ E. TUDELA, ${ }^{1}$ R. ROSSELLÓ-MORA, ${ }^{2}$ J. LALUCAT, ${ }^{2}$ AND J. GUINEA ${ }^{1 *}$ \\ Laboratorio de Microbiología, Facultad de Farmacia, Universitat de Barcelona, 08028 Barcelona, ${ }^{1}$ and \\ Instituto Mediterráneo de Estudios Avanzados (CSIC-UIB) and Departamento de Biología \\ Ambiental, Universitat de les Illes Balears, 07071 Palma de Mallorca, ${ }^{2}$ Spain
}

\begin{abstract}
The taxonomic characteristics of five bacterial strains which were isolated from Antarctic coastal marine environments were studied. These bacteria were psychrotrophic, aerobic, and gram negative with polar flagella. The G+C contents of the DNAs of these strains were 41 to 42 mol\%. The Antarctic strains were phenotypically distinct from the previously described Pseudoalteromonas type species. DNA-DNA hybridization experiments revealed that the new strains were closely related to each other but clearly different from Pseudoalteromonas haloplanktis and Pseudoalteromonas atlantica, which were the most phenotypically similar organisms. None of the bacterial isolates was capable of using DL-malate, D-sorbitol, or $m$-hydroxybenzoate, and all were capable of gelatin hydrolysis. Strains NF2, $\mathrm{NF3}^{\mathrm{T}}$ (T = type strain), NF13, NF14, and $\mathrm{EN10}$ had an $\mathrm{Na}^{+}$requirement but required only $17 \mathrm{mM} \mathrm{Na}{ }^{+}$. Phenotypic, DNA G+C content, DNA-DNA hybridization, 16S rRNA analysis, fatty acid composition, and protein profile data confirmed the identification of the Antarctic strains as members of a Pseudoalteromonas sp. The name Pseudoalteromonas antarctica sp. nov. is proposed for these organisms.
\end{abstract}

The genus Pseudoalteromonas (15), originally called Alteromonas, included nonpigmented, gram-negative, heterotrophic, aerobic, polarly flagellated species of marine bacteria which had $\mathrm{G}+\mathrm{C}$ contents ranging from 38 to $50 \mathrm{~mol} \%$, which differentiated this bacterial group from the previously described genus Pseudomonas $(4,5,7,20)$. Since Baumann et al. (4) created the genus Alteromonas in 1972, several species have been assigned to this genus $(2,6,9,12,16-19,22,25,28,30,41$, 48 ), although a recent revision of genera based on phylogenetic analysis by Gauthier et al. (15) divided the genus Alteromonas into two genera, the genera Pseudoalteromonas and Alteromonas. Separation of Pseudoalteromonas species on the basis of phenotypic characteristics is problematic because of significant variations in phenotypic traits (23) and because phenotypic differences have frequently been observed even among genetically closely related strains (1). Thus, in order to determine the relationships between Pseudoalteromonas species, genetic and chemotaxonomic methods appear to provide more reliable information than differential phenotypic characteristics.

The aim of this work was to describe a taxonomic study of some aerobic heterotrophic bacteria isolated from samples collected in the South Shetland Islands (Antarctica) by a Spanish scientific expedition during the Antarctic summer of 1987 and 1988. Part of the microbiota was composed of motile nonpigmented rods. Five of these bacterial strains, strains NF2, $\mathrm{NF}^{\mathrm{T}}$ ( $\mathrm{T}=$ type strain), NF13, NF14, and EN10, belong to the genus Pseudoalteromonas. In this study, morphological, phenotypic, genetic, and chemotaxonomic analyses were performed to clarify the taxonomic position of these bacterial isolates. Our results show that this bacterial group from an Antarctic environment constitute a new species of the recently proposed genus Pseudoalteromonas.

\section{MATERIALS AND METHODS}

Bacterial strains and isolation. Strains $\mathrm{NF} 2, \mathrm{NF}^{\mathrm{T}}, \mathrm{NF} 12, \mathrm{NF} 13$, and NF14 were isolated from mud collected in the inlet Admiralty Bay (King George

\footnotetext{
* Corresponding author. Mailing address: Laboratorio de Microbiología, Facultad de Farmacia, Universitat de Barcelona, Avd. Diagonal s/n, 08028 Barcelona, Spain. Phone: (34 3) 4024497. Fax: (34 3) 4021886.
}

Island, South Shetland Islands) at the bottom of a glacier which is covered at high water Strain EN10 was isolated from sediment collected in Johnson's Dock (Livingston Island, South Shetland Islands).

Aliquots of samples were removed with a platinum loop and diluted in a saline solution $\left(0.56 \mathrm{~g}\right.$ of $\mathrm{NaCl}$ per liter, $0.27 \mathrm{~g}$ of $\mathrm{KCl}$ per liter, $0.03 \mathrm{~g}$ of $\mathrm{CaCl}_{2}$ per liter, $0.01 \mathrm{~g}$ of $\mathrm{NaHCO}_{3}$ per liter; pH 7). Trypticase soy agar (TSA) (ADSA, Barcelona, Spain) plates were inoculated with loopfuls of different sample dilutions by using the streak plate method to obtain well-isolated colonies. The petri dishes were incubated for 6 days at $15^{\circ} \mathrm{C}$. Isolates were maintained on TSA slopes at $4^{\circ} \mathrm{C}$. Bacteria were also stored at $-20^{\circ} \mathrm{C}$ in $50 \%$ (vol $/ \mathrm{vol}$ ) glycerol. All media used in this study were sterilized at $121^{\circ} \mathrm{C}$ for $20 \mathrm{~min}$, unless otherwise indicated.

The following previously described strains of Pseudoalteromonas species were used in this study: Pseudoalteromonas sp. strain CECT 579 (= ATCC 19262 [American Type Culture Collection, Rockville, Md.]) and Pseudoalteromonas haloplanktis CECT 4188 (= ATCC $14393^{\mathrm{T}}$ ), both of which were obtained from the Spanish Type Culture Collection (Colección Española de Cultivos Tipo [CECT], Valencia, Spain); and Pseudoalteromonas atlantica IAM 14165 (Institute of Applied Microbiology, University of Tokyo, Tokyo, Japan), IAM 14164 IAM 14163, IAM 14162, IAM $12927^{\mathrm{T}}$ (= ATCC 19262 ${ }^{\mathrm{T}}$ ), and IAM 14161 and Pseudoalteromonas carragenovora IAM $12662^{\mathrm{T}}$ (= ATCC $43555^{\mathrm{T}}$ ), which were provided by M. Akagawa-Matsushita (2).

Morphology. Cell size and morphology were determined by scanning electron microscopy of cells grown in Trypticase soy broth (TSB) (ADSA) at $15^{\circ} \mathrm{C}$. A Hitachi model S 3200 scanning electron microscope was used. Motility was determined by phase-contrast microscopy. Flagellar arrangement was examined with a Philips model 301 microscope following negative staining with $0.5 \%$ (wt/vol) phosphotungstic acid adjusted to $\mathrm{pH} 6$ with $1 \mathrm{~N}$ KOH. TSB cultures, grown for $24 \mathrm{~h}$, were used.

Biochemical and physiological tests. Oxidative or fermentative utilization of glucose was determined by the method of Hugh and Leifson (21) after incubation at $15^{\circ} \mathrm{C}$ for 14 days. Oxidase activity was tested by the Kovács method (29). Catalase activity, nitrate reduction, and the lecithovitelin reaction were determined by the methods of Cowan and Steel (10). The arginine dihydrolase reaction test was performed by the method of Thornley (45), as modified by Lelliot et al. (31)

Degradative tests were carried out at $15^{\circ} \mathrm{C}$. Tween $80(1 \%$, vol/vol) was incorporated into Sierra's medium (40), and plates were examined for opacity after 5 days. Hydrolysis of DNA was tested by the method of Jeffries et al. (24), and starch hydrolysis was tested by the method of Cowan and Steel (10).

Media A and B of King et al. (27) were used to study the production of pyoverdin and phenazine pigments. Growth on selective media, such as $\mathrm{MacCo}$ nkey agar, cetrimide agar, and Simmons citrate agar (ADSA), was also tested.

API tests, including the API 20NE (identification system for gram-negative nonenterobacterial rods), ATB 32GN (automatic identification system for gramnegative rods), API $20 \mathrm{~B}$ (study system for aerobic heterotrophic bacteria), and API ZYM (enzyme activity) tests (API System, La Balme les Grottes, Montalieu Vercieu, France) were performed according to the manufacturer's instructions. The API strips were incubated for 5 days at $15^{\circ} \mathrm{C}$

The $\mathrm{pH}$ range for the growth of each strain was determined in TSB with the $\mathrm{pH}$ values of separate batches of media adjusted to $4,5,6,7,8,9$, and 9.5 with $1 \mathrm{~N} \mathrm{HCl}$ and $1 \mathrm{~N} \mathrm{NaOH}$. The test media were incubated at $15^{\circ} \mathrm{C}$ for 14 days. The 


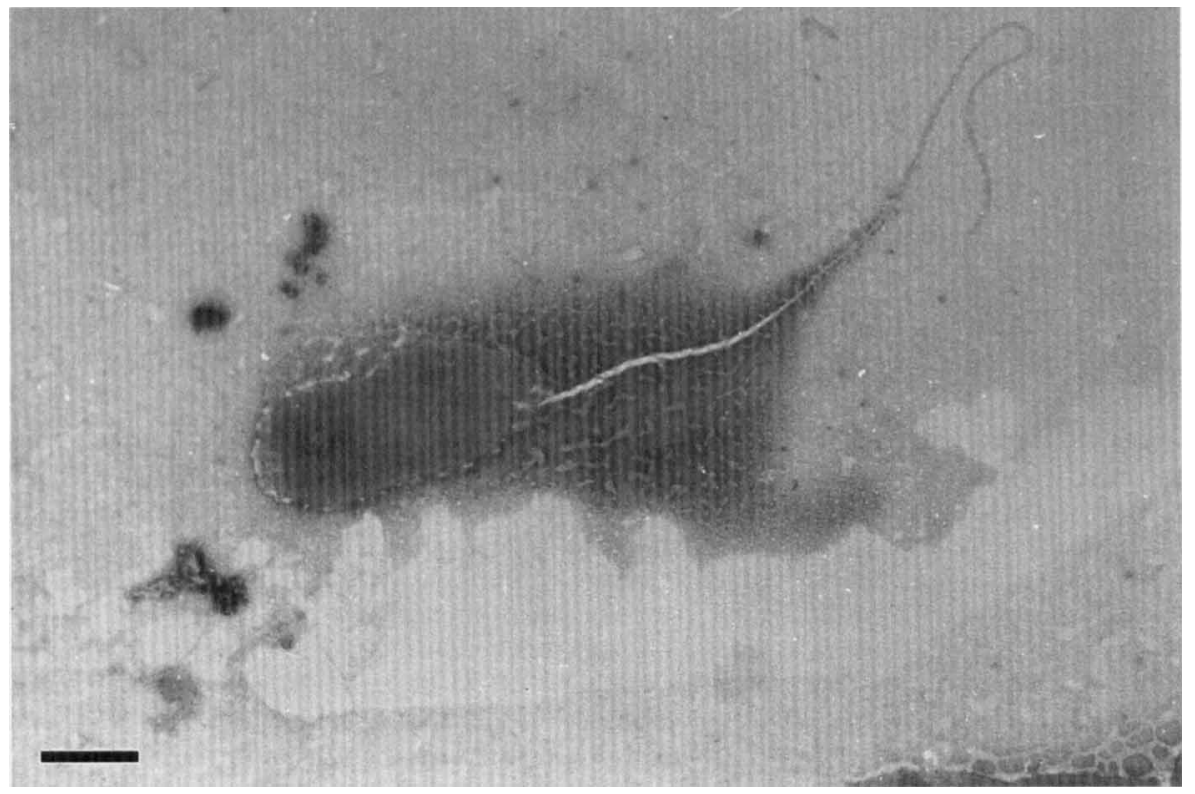

FIG. 1. Electron micrograph of negatively stained cell of $\mathrm{NF}^{\mathrm{T}}$ from a liquid culture after $24 \mathrm{~h}$ of incubation at $15^{\circ} \mathrm{C} . \mathrm{Bar}=0.7 \mu \mathrm{m}$.

temperature range for growth was determined on TSA and TSA containing $3 \%$ (wt/vol) $\mathrm{NaCl}$, which were incubated for 14 days at $4,11,16,20,25,30,37$, and $40^{\circ} \mathrm{C}$. Salt tolerance tests were performed on TSA with $\mathrm{NaCl}$ concentrations ranging from 0.6 to $20 \%$ (wt/vol). Growth at $15^{\circ} \mathrm{C}$ was recorded for 25 days.

The sodium requirement was analyzed in medium containing (per liter) $5.0 \mathrm{~g}$ of $\mathrm{K}_{2} \mathrm{HPO}_{4}, 0.5 \mathrm{~g}$ of $\mathrm{MgSO}_{4} \cdot 7 \mathrm{H}_{2} \mathrm{O}, 0.05 \mathrm{~g}$ of $\mathrm{CaCl}_{2}, 0.028 \mathrm{~g}$ of $\mathrm{FeSO}_{4} \cdot 7 \mathrm{H}_{2} \mathrm{O}$ $7.0 \mathrm{~g}$ of $\mathrm{NH}_{4} \mathrm{Cl}, 5.0 \mathrm{~g}$ of yeast extract, and $20.0 \mathrm{~g}$ of agar ( $\mathrm{pH} 7$ ). Another medium with the same composition except that it contained $1 \mathrm{~g}$ of $\mathrm{NaCl}$ per liter was used as a positive control. A solution with all of the ingredients except $\mathrm{CaCl}_{2}$ and $\mathrm{FeSO}_{4}$ was sterilized by autoclaving it at $0.5 \mathrm{~atm}$ for $30 \mathrm{~min}$. $\mathrm{CaCl}_{2}$ and $\mathrm{FeSO}$ were added aseptically from sterile stock solutions. Plates were incubated for 14 days at $15^{\circ} \mathrm{C}$

Carbon source utilization tests were performed in a mineral medium containing (per liter) $10.0 \mathrm{~g}$ of $\mathrm{Na}_{2} \mathrm{HPO}_{4}, 3.0 \mathrm{~g}$ of $\mathrm{KH}_{2} \mathrm{PO}_{4}, 1.0 \mathrm{~g}$ of $\mathrm{K}_{2} \mathrm{SO}_{4}, 1.0 \mathrm{~g}$ of $\mathrm{NaCl}, 0.4 \mathrm{~g}$ of $\mathrm{MgSO}_{4} \cdot 7 \mathrm{H}_{2} \mathrm{O}, 0.1 \mathrm{~g}$ of $\mathrm{CaCl}_{2}, 0.018 \mathrm{~g}$ of $\mathrm{FeSO}_{4} \cdot 7 \mathrm{H}_{2} \mathrm{O}$, and $3.0 \mathrm{~g}$ of $\mathrm{NH}_{4} \mathrm{Cl}(\mathrm{pH} 7)$. The carbon source concentration used was $0.1 \%$, as described by Palleroni and Doudoroff (37).

Susceptibility to antibiotics. Susceptibility to antibiotics was tested by using the method of Bauer et al. (3). Disks (diameter, $6.5 \mathrm{~mm}$ ) impregnated with antibiotics (Biomerieux) were laid on Müller-Hinton agar (ADSA) plates which had been surface inoculated with test strains. The following disks were used: penicillin (10 IU), chloramphenicol $(30 \mu \mathrm{g})$, nalidixic acid $(30 \mu \mathrm{g})$, tobramycin $(10 \mu \mathrm{g})$, and tetracycline $(30 \mu \mathrm{g})$.

Fatty acid analysis. Fatty acids were prepared from $40 \mathrm{mg}$ of wet cell material harvested from a TSB agar ( $30 \mathrm{~g}$ of TSB, $15 \mathrm{~g}$ of agar; BBL) culture incubated for 5 days at $15^{\circ} \mathrm{C}$. The whole-cell fatty acids were isolated as recommended by the Microbial Identification System (MIS) instructions (Microbial ID, Inc., Newark, Del.) and were analyzed by gas-liquid chromatography with a HewlettPackard model HP5890A instrument. Fatty acids were identified and quantified by comparing the results with the fatty acid patterns of other microorganisms, using MIDI System software, version 3.2. The relative amount of each fatty acid in a strain was expressed as a percentage of the total fatty acids in the profile of that strain.

SDS-PAGE of whole-cell proteins. To obtain whole-cell protein extracts, the Antarctic isolates and Pseudoalteromonas species were grown on TSA-3\% (wt/ vol) $\mathrm{NaCl}$ plates for 5 days at $15^{\circ} \mathrm{C}$ and at the ambient temperature $\left(22^{\circ} \mathrm{C}\right.$ ), respectively. The bacterial growth on three petri dishes was harvested and resuspended in $7 \mathrm{ml}$ of NaPBS buffer ( $0.2 \mathrm{M}$ sodium phosphate buffer [pH 7.3], $8 \mathrm{~g}$ of $\mathrm{NaCl}$ per liter). The bacterial suspension was filtered through nylon gauze and centrifuged for $20 \mathrm{~min}$ at $5,000 \times \mathrm{g}$. The pellet was washed twice in the same buffer, and $70 \mathrm{mg}$ (wet weight) of bacterial cells was transferred to an Eppendor centrifuge tube. A $0.9-\mathrm{ml}$ portion of sample treatment buffer $(0.75 \mathrm{~g}$ of Tris, $5 \mathrm{ml}$ of mercaptoethanol, $5 \mathrm{~g}$ of sucrose, and enough deionized water to bring the volume up to $100 \mathrm{ml} ; \mathrm{pH} 6.8$ ) was added, and the solution was mixed. Then 0.1 $\mathrm{ml}$ of $20 \%$ sodium dodecyl sulfate (SDS) was added. The mixture was incubated at $95^{\circ} \mathrm{C}$ for $10 \mathrm{~min}$, cooled on ice, and centrifuged at $11,000 \times \mathrm{g}$ for $5 \mathrm{~min}$ in an Eppendorf centrifuge. Supernatants were stored at $-20^{\circ} \mathrm{C}$. SDS-polyacrylamide gel electrophoresis (PAGE) of the whole-cell protein extracts was performed by the procedure of Sambrook et al. (38) in a Miniprotean II electrophoresis cell (Bio-Rad Laboratories, Richmond, Calif.) by using $12 \%$ separation gels. The gels were stained with Coomassie blue.
Determination of DNA base composition. Cells from a culture of each isolate were harvested, washed, and suspended in $0.15 \mathrm{M} \mathrm{NaCl}-0.01 \mathrm{M}$ sodium EDTA buffer ( $\mathrm{pH} 8.0$ ). The cells were lysed at $60^{\circ} \mathrm{C}$ for $10 \mathrm{~min}$ by adding SDS to a final concentration of $1 \%(\mathrm{wt} / \mathrm{vol})$. The DNA was extracted and purified by the method of Marmur (33). The guanine-plus-cytosine $(\mathrm{G}+\mathrm{C})$ content was determined from the midpoint $\left(T_{m}\right)$ of the thermal denaturation profile (34) obtained with a Perkin-Elmer model UV-Vis 551S spectrophotometer at $260 \mathrm{~nm}$. The $T_{m}$ was determined by the method described by Ferragut and Leclerc (14), and the $\mathrm{G}+\mathrm{C}$ content was calculated by using the equation of Owen and Hill (35). The $T_{m}$ of reference DNA from Escherichia coli NCTC 9001 in $0.1 \times$ SSC $(1 \times$ SSC is $0.15 \mathrm{M} \mathrm{NaCl}$ plus $0.015 \mathrm{M}$ sodium citrate) was $74.6^{\circ} \mathrm{C}(36)$

DNA-DNA hybridization. Levels of DNA-DNA hybridization between bacterial isolates and type strains were determined spectrophotometrically by the initial renaturation method of De Ley et al. (11). DNA-DNA similarity was also measured by the quantitative bacterial dot filter method described by Tjernberg et al. (46). In this case DNAs were labeled with ${ }^{125} \mathrm{I}$ by the method described by Selin et al. (39).

$16 S$ rRNA gene sequence and data analysis. In vitro amplification of the 16 rRNA gene and direct sequencing of the amplified DNA fragments were performed as previously described (42). The new sequence was added to an alignment of about 4,500 homologous bacterial 16S rRNA primary structures by using the aligning tool of the ARB program package (44). Similarity and distance matrices were calculated with the program ARB-PHYL of the same package. Phylogenetic trees were constructed by using subsets of data that included representative sequences of Alteromonas and Pseudoalteromonas species $(15,32)$. We used distance matrix and maximum-likelihood methods as implemented in the programs PHYLIP (13), ARB, and fastDNAml (32).

Nucleotide sequence accession number. The nearly complete sequence of the $16 \mathrm{~S}$ rRNA gene of strain NF3 ${ }^{\mathrm{T}}$ has been deposited in the EMBL sequence database under accession number X98336.

\section{RESULTS}

Morphological and cultural characteristics. During isolation and laboratory cultivation, the Antarctic bacterial isolates grew as uniformly round, slightly convex, smooth, mucoid colonies that were nonpigmented and 1 to $2 \mathrm{~mm}$ in diameter after 5 days of incubation at $15^{\circ} \mathrm{C}$ in TSA. The cells of young cultures were exclusively rod shaped, gram negative, and motile by means of a single polar flagellum (Fig. 1). After $24 \mathrm{~h}$ of incubation, larger cells appeared in the population, and sometimes filament forms about $10 \mu \mathrm{m}$ long were observed. The strains were moderately halophilic and tolerated $\mathrm{NaCl}$ levels of about 9 to $12.5 \%$. All of the isolates required $\mathrm{Na}^{+}$at a concentration of $17 \mathrm{mM}(0.1 \%$ [wt/vol] $\mathrm{NaCl})$. The growth temperature range was 4 to $30^{\circ} \mathrm{C}$, and the $\mathrm{pH}$ range for growth was 6 to 9.5 . 
TABLE 1. Characteristics of five strains isolated from Antarctic marine environments

\begin{tabular}{|c|c|c|c|c|c|}
\hline Characteristic & EN10 & NF2 & $\mathrm{NF} 3^{\mathrm{T}}$ & NF13 & NF14 \\
\hline Cell shape & $\mathrm{St}^{a}$ & St & St & St & St \\
\hline Cell length $(\mu \mathrm{m})$ & $2-3$ & $1-3$ & $1-3$ & $0.7-3$ & $1-2$ \\
\hline Cell diam $(\mu \mathrm{m})$ & $0.7-0.9$ & $0.4-0.8$ & $0.5-0.8$ & 0.5 & 0.5 \\
\hline Polar flagellum & $+^{b}$ & + & + & + & + \\
\hline Catalase test & + & + & + & + & + \\
\hline Oxidase test & + & + & + & + & + \\
\hline Nitrate reduction & - & - & - & - & - \\
\hline Oxidation/fermentation & $-1-$ & $-1-$ & $-1-$ & $-1-$ & $-1-$ \\
\hline $\mathrm{Na}^{+}$requirement & + & + & + & + & + \\
\hline Temp range for growth $\left({ }^{\circ} \mathrm{C}\right)$ & $4-30$ & $4-30$ & $4-30$ & $4-30$ & $4-30$ \\
\hline Maximum $\mathrm{NaCl}$ concn tolerated (\%, wt $/ \mathrm{vol})$ & 9 & 9.5 & 12.5 & 9.5 & 12.5 \\
\hline Urease & + & - & - & - & - \\
\hline Esculin hydrolysis & + & - & - & - & - \\
\hline Gelatin hydrolysis & + & + & + & + & + \\
\hline Casein hydrolysis & + & + & + & + & + \\
\hline Tween 80 hydrolysis & - & + & + & + & - \\
\hline Starch hydrolysis & + & - & - & - & - \\
\hline DNase & + & - & - & - & - \\
\hline Lecithinase (egg yolk) & - & - & - & + & - \\
\hline Indole & - & - & - & - & - \\
\hline $\mathrm{H}_{2} \mathrm{~S}$ production & + & - & - & - & - \\
\hline Voges-Proskauer reaction & - & + & + & + & + \\
\hline Arginine dihydrolase & - & - & - & - & - \\
\hline $\mathrm{G}+\mathrm{C}$ content $(\mathrm{mol} \%)$ & 41 & 41 & 42 & 42 & 41 \\
\hline \multicolumn{6}{|l|}{ Acid produced from: } \\
\hline Sucrose & - & - & - & - & - \\
\hline L- $(+)$-Arabinose & - & - & - & - & - \\
\hline Fructose & - & - & - & - & - \\
\hline Glucose & + & + & + & + & + \\
\hline Maltose & + & + & + & + & + \\
\hline Starch & + & + & + & + & + \\
\hline Rhamnose & - & - & - & - & - \\
\hline Galactose & + & + & + & + & + \\
\hline Mannose & - & + & + & - & - \\
\hline Sorbitol & - & - & - & - & - \\
\hline Glycerol & + & - & - & - & - \\
\hline Mannitol & + & + & + & + & + \\
\hline \multicolumn{6}{|l|}{ Susceptibility to: } \\
\hline Penicillin (10 U/disk) & - & + & + & + & + \\
\hline Tobramycin $(10 \mu \mathrm{g} /$ disk $)$ & + & + & + & + & + \\
\hline Nalidixic acid $(30 \mu \mathrm{g} / \mathrm{disk})$ & - & + & + & + & + \\
\hline Chloramphenicol (30 $\mu \mathrm{g} /$ disk $)$ & + & + & + & + & + \\
\hline Tetracycline $(30 \mu \mathrm{g} /$ disk $)$ & + & + & + & + & + \\
\hline \multicolumn{6}{|l|}{ Growth on selective media } \\
\hline MacConkey agar & + & + & + & + & + \\
\hline Cetrimide agar & + & - & - & - & - \\
\hline Simmons citrate agar & - & - & - & - & - \\
\hline \multicolumn{6}{|l|}{ Utilization of: } \\
\hline D-Glucose, D-mannitol, maltose & + & + & + & + & + \\
\hline D-Mannose & - & + & + & - & - \\
\hline $\mathrm{N}$-Acetylglucosamine & - & + & + & - & - \\
\hline Gluconate & + & + & + & - & + \\
\hline Malonate & + & - & - & + & + \\
\hline Citrate & - & + & + & + & + \\
\hline Glycogen & + & + & - & - & - \\
\hline 3-Hydroxybutyrate & NT & + & - & + & + \\
\hline L-Serine & NT & - & - & + & + \\
\hline L-Proline, L-alanine, succinate, L-glutamate & NT & + & + & + & + \\
\hline 5-Ketogluconate, D-cellobiose & + & - & - & - & - \\
\hline $\begin{array}{l}\text { L-Arabinose, D-arabinose, caprate, adipate, phenylacetate, salicin, } \\
\text { D-melobiose, L-fucose, D-sorbitol, 2-ketogluconate, } \alpha \text {-L-rhamnose, } \\
\text { D-ribose, inositol, sucrose, 3-hydroxybenzoate, DL-malate, } \alpha- \\
\text { lactose, D-fructose }\end{array}$ & - & - & - & - & - \\
\hline $\begin{array}{l}\text { Valerate, histidine, 4-hydroxybenzoate, itaconate, suberate, acetate, } \\
\text { DL-lactate, propionate, pimelate, D-xylose, sebacate, } m \text {-tartrate, } \\
\text { DL-hydroxybutyrate, L-phenylalanine }\end{array}$ & NT & - & - & - & - \\
\hline
\end{tabular}

${ }_{b}^{a}$ St, straight rod.

${ }^{b}+$, positive; - , negative; NT, not tested. 
TABLE 2. Differential characteristics of Pseudoalteromonas species ${ }^{a}$

\begin{tabular}{|c|c|c|c|c|c|c|}
\hline Characteristics & P. atlantica & P. haloplanktis & P. espejiana & P. undina & P. nigrifaciens & P. antarctica \\
\hline Cell shape ${ }^{b}$ & St & St & St & $\mathrm{Cu}$ & St & St \\
\hline \multicolumn{7}{|l|}{ Growth at: } \\
\hline $4^{\circ} \mathrm{C}$ & $+^{c}$ & - & - & $\mathrm{d}$ & + & + \\
\hline $35^{\circ} \mathrm{C}$ & + & $\mathrm{d}$ & $\mathrm{d}$ & - & - & - \\
\hline Requirement for organic growth factors & 1 & $\mathrm{~d}$ & + & + & + & - \\
\hline Production of lipase & 1 & + & + & + & + & - \\
\hline Hydrolysis of agar & + & - & - & - & - & - \\
\hline \multicolumn{7}{|l|}{ Utilization of: } \\
\hline D-Fructose & + & $\mathrm{d}$ & $\mathrm{d}$ & - & + & - \\
\hline Sucrose & + & + & + & + & - & - \\
\hline Lactose & + & - & + & - & + & - \\
\hline L-Glutamate & 1 & $\mathrm{~d}$ & - & - & - & + \\
\hline Succinate & + & + & - & + & + & + \\
\hline DL-Lactate & - & - & - & - & + & - \\
\hline D-Mannitol & + & $\mathrm{d}$ & + & - & - & + \\
\hline Production of melanin & - & - & - & - & + & - \\
\hline $\mathrm{G}+\mathrm{C}$ content $(\mathrm{mol} \%)$ & $40.6-41.7$ & $41-45$ & $43-44$ & $43-44$ & $39-41$ & $41-42$ \\
\hline
\end{tabular}

${ }^{a}$ Data from references $2,7,20$, and 26

${ }^{b} \mathrm{St}$, straight rod; $\mathrm{Cu}$, curved rod.

${ }^{c}+$, positive; -, negative; d, 11 to $89 \%$ of the strains are positive; /, no data available.

Phenotypic characterization and $G+C$ content of DNA. The physiological and biochemical properties of the Antarctic isolates are summarized in Table 1 . The strains were chemoorganotrophic and capable of respiratory but not fermentative metabolism. All of the strains were oxidase and catalase positive. They hydrolyzed gelatin and casein. They did not have a constitutive arginine dihydrolase system. They were positive in the alkaline and acid phosphatase, esterase (C4), esterase lipase (C8), leucine, cystine and valine arylamidase, and naphthol-AS-BI-phosphohydrolase tests, and they were negative in the $\beta$-galactosidase ( $o$-nitrophenyl- $\beta$-D-galactopyranoside), lipase (C14), $\beta$-glucuronidase, $\beta$-glucosidase, and $\alpha$-fucosidase tests. All of the strains except EN10 were positive in the trypsin, $\alpha$-chymotrypsin, and $\alpha$-glucosidase tests and negative in the $\alpha$-galactosidase test. NF13 and EN10 were negative in the $N$-acetyl- $\beta$-glucosaminidase and $\alpha$-mannosidase tests, and NF2, NF3 ${ }^{\mathrm{T}}$, and NF14 were positive in these tests. Strain EN10 was resistant to penicillin and nalidixic acid and susceptible to tobramycin, chloramphenicol, and tetracycline. The rest of the strains were susceptible to all of the antibiotics tested. Acid was produced from glucose, maltose, starch, galactose, and mannitol. Carbon source assimilation by the isolates is shown in Table 1. All of the strains utilized glucose, maltose, and D-mannitol for growth. Malate, sorbitol, and $m$ hydroxybenzoate were some of the substrates that were not assimilated by the strains. The DNA base compositions of the strains ranged from 41 to $42 \mathrm{~mol} \% \mathrm{G}+\mathrm{C}$ (Table 1 ).

The phenotypic characteristics and DNA G+C contents (Table 1) suggested that the Antarctic isolates belonged to the genus Pseudoalteromonas. The results of the biochemical and physiological studies of these organisms allowed us to distinguish them from the similar nonpigmented Pseudoalteromonas species, such as $P$. atlantica, $P$. haloplanktis, Pseudoalteromonas espejiana, Pseudoalteromonas undina, and Pseudoalteromonas nigrifaciens. The differential characteristics of these Pseudoalteromonas species and the Antarctic strains are shown in Table 2.

Fatty acid composition. A fatty acid analysis with the automated MIS identified NF2, NF3 ${ }^{\mathrm{T}}$, NF13, NF14, and EN10 as $P$. haloplanktis strains with a good index correlation at the genus level. The fatty acid compositions of the bacterial isolates and the reference strains are shown in Table 3 . The major fatty acids were $16: 1 \omega 7 \mathrm{c}, 16: 0$, and $17: 1 \omega 8 \mathrm{c}$ or $12: 03 \mathrm{OH}$. In general, there was a high level of similarity between the fatty acid patterns of the isolated bacteria and the reference Pseudoalteromonas strains.

SDS-PAGE protein profile patterns. The total-protein-profile patterns of strains NF2, NF3 ${ }^{\mathrm{T}}$, NF13, NF14, and EN10 were identical and were very similar to the profiles of $P$. haloplanktis CECT $4188^{\mathrm{T}}$ (Fig. 2) and Pseudoalteromonas sp. strain CECT 579, but less similar to the protein profile of $P$. atlantica IAM 14164.

DNA-DNA binding studies. The results of DNA-DNA hybridization experiments are shown in Table 4. The levels of DNA-DNA relatedness calculated spectrophotometrically between the isolates and $P$. haloplanktis CECT $4188^{\mathrm{T}}$ ranged from 20 to $22 \%$. The results of DNA binding as determined by the filter method and expressed as $\Delta T_{m}\left(\Delta T_{m}\right.$ is the difference between the $T_{m}$ of a homoduplex and the $T_{m}$ of a heteroduplex) indicated that the distances between strains NF2, NF3 ${ }^{\mathrm{T}}$, NF13, NF14, and EN10 and type strain IAM 12927 were great, $\left(\Delta T_{m}\right.$ values were between 7.0 and $\left.8.0^{\circ} \mathrm{C}\right)$. In contrast, the $\Delta T_{m}$ values for the reference $P$. atlantica strains and strain IAM $12927^{\mathrm{T}}$ ranged from 2.9 to $4.6^{\circ} \mathrm{C}$. The $\Delta T_{m}$ values were $2.4^{\circ} \mathrm{C}$ or less when NF2, NF13, NF14, and EN10 were hybridized with $\mathrm{NF}^{\mathrm{T}}$. The DNA-DNA hybridization results showed that NF2, $\mathrm{NF}^{\mathrm{T}}$, NF13, NF14, and EN10 constituted a homogeneous group that was clearly different from $P$. haloplanktis CECT $4188^{\mathrm{T}}$ and $P$. atlantica IAM $12927^{\mathrm{T}}$.

Phylogenetic affiliation. The phylogenetic affiliation of strain $\mathrm{NF}^{\mathrm{T}}$ was studied by distance and maximum-likelihood methods. P. haloplanktis subsp. haloplanktis was the closest relative of NF3 ${ }^{\mathrm{T}}$, with a level of sequence similarity of $99 \%$. The results of all treeing approaches were consistent with affiliation of $\mathrm{NF}^{\mathrm{T}}$ with the genus Pseudoalteromonas, as well as clustering in the same branch as P. haloplanktis subsp. haloplanktis (Fig. 3 ). The tree topologies were also consistent with previously reported results (15).

\section{DISCUSSION}

The five bacterial strains which we investigated were isolated from muddy soils and sediments of Antarctic coastal areas. These organisms were nonpigmented, motile, gram-negative 
TABLE 3. Fatty acid compositions of bacterial isolates and reference strains ${ }^{a}$

\begin{tabular}{|c|c|c|c|c|c|c|c|c|}
\hline \multirow{2}{*}{ Fatty acid } & \multicolumn{8}{|c|}{$\%$ of total fatty acids in: } \\
\hline & CECT $4188^{\mathrm{T}}$ & CECT 579 & IAM 14164 & EN10 & NF2 & $\mathrm{NF}^{\mathrm{T}}$ & NF13 & $\overline{N F 14}$ \\
\hline $10: 3 \mathrm{OH}$ & $\mathrm{Tr}$ & 1.0 & 1.4 & & $\operatorname{Tr}$ & $\operatorname{Tr}$ & & $\operatorname{Tr}$ \\
\hline $12: 0$ & 2.8 & 2.1 & 2.5 & 3.3 & 3.1 & 1.9 & 3.2 & 2.7 \\
\hline $11: 0$ iso $3 \mathrm{OH}$ & $\operatorname{Tr}$ & $\operatorname{Tr}$ & $\operatorname{Tr}$ & $\operatorname{Tr}$ & 1.8 & $\mathrm{Tr}$ & $\operatorname{Tr}$ & $\operatorname{Tr}$ \\
\hline $11: 03 \mathrm{OH}$ & $\mathrm{Tr}$ & 4.0 & 1.8 & & $\operatorname{Tr}$ & 1.4 & 1.2 & 1.6 \\
\hline $12: 0$ iso $3 \mathrm{OH}$ & 1.4 & & & $\operatorname{Tr}$ & $\operatorname{Tr}$ & 1.3 & $\operatorname{Tr}$ & 1.2 \\
\hline $12: 03 \mathrm{OH}$ & 6.4 & 3.7 & 3.8 & 7.9 & 6.8 & 4.6 & 7.2 & 5.3 \\
\hline $14: 0$ & 1.3 & $\operatorname{Tr}$ & 0.7 & 2.0 & 2.3 & 1.0 & 2.0 & 1.2 \\
\hline $13: 0$ iso $3 \mathrm{OH}$ & & & & $\operatorname{Tr}$ & $\mathrm{Tr}$ & $\operatorname{Tr}$ & & $\operatorname{Tr}$ \\
\hline $15: 0$ iso & & $\operatorname{Tr}$ & & $\operatorname{Tr}$ & 1.2 & $\operatorname{Tr}$ & & $\operatorname{Tr}$ \\
\hline $15: 1 \omega 8 \mathrm{c}$ & $\mathrm{Tr}$ & 3.6 & $\operatorname{Tr}$ & $\operatorname{Tr}$ & 2.5 & 4.5 & 3.7 & 4.5 \\
\hline $15: 0$ & 1.2 & 7.3 & 2.7 & $\operatorname{Tr}$ & 3.3 & 7.8 & 5.8 & 8.3 \\
\hline $16: 0$ iso & 1.7 & & $\mathrm{Tr}$ & $\mathrm{Tr}$ & $\operatorname{Tr}$ & 1.4 & $\operatorname{Tr}$ & 1.2 \\
\hline $16: 1 \omega 9 \mathrm{c}$ & & $\operatorname{Tr}$ & & 1.7 & 1.6 & $\operatorname{Tr}$ & $\mathrm{Tr}$ & $\operatorname{Tr}$ \\
\hline $16: 1 \omega 7 c$ & 34.8 & 19.5 & 22.0 & 38.7 & 33.3 & 30.9 & 32.5 & 25.6 \\
\hline $16: 0$ & 20.1 & 11.6 & 19.4 & 24.4 & 17.7 & 14.3 & 18.4 & 14.1 \\
\hline $17: 0$ iso & $\operatorname{Tr}$ & $\mathrm{Tr}$ & $\mathrm{Tr}$ & 2.7 & 4.2 & 1.1 & 1.7 & 1.8 \\
\hline 17:0 anteiso & 2.1 & & $\operatorname{Tr}$ & & 1.0 & $\mathrm{Tr}$ & & 1.6 \\
\hline $17: 1 \omega 8 \mathrm{c}$ & 3.5 & 15.7 & 8.2 & 1.5 & 4.7 & 15.1 & 7.5 & 13.5 \\
\hline $17: 0$ & 1.2 & 8.9 & 9.6 & $\operatorname{Tr}$ & 1.0 & 4.9 & 2.4 & 3.8 \\
\hline $18: 1 \omega 9 \mathrm{c}$ & $\mathrm{Tr}$ & & $\mathrm{Tr}$ & $\mathrm{Tr}$ & $\operatorname{Tr}$ & $\operatorname{Tr}$ & & $\mathrm{Tr}$ \\
\hline 18:0 & $\operatorname{Tr}$ & $\operatorname{Tr}$ & 1.9 & $\operatorname{Tr}$ & $\operatorname{Tr}$ & $\mathrm{Tr}$ & $\operatorname{Tr}$ & $\operatorname{Tr}$ \\
\hline Summed feature $2^{b}$ & & 1.5 & $\operatorname{Tr}$ & & $\mathrm{Tr}$ & 1.1 & $\mathrm{Tr}$ & 1.1 \\
\hline Summed feature $4^{c}$ & 10.7 & 10.3 & 9.7 & 7.3 & 7.3 & & 7.4 & 2.8 \\
\hline Summed feature $7^{d}$ & 7.0 & 4.5 & 8.6 & 3.9 & 1.4 & 2.6 & 1.6 & 1.4 \\
\hline
\end{tabular}

${ }^{a}$ In addition, small amounts (less than $3 \%$ of the total fatty acids) of one or more of the following fatty acids occur in the strains studied: 10:0, 11:0, unknown 11.798 (fatty acid whose identity is unknown and whose equivalent chain length is 11.798), 13:0, 13:0 iso, 13:0 2OH, 15:0 anteiso, 15:1 w6c, 15:0 iso 3OH, and 18:0 iso.

${ }^{b}$ Fatty acids 13:0 $3 \mathrm{OH}, 15: 1$ iso I, and 15:1 iso $\mathrm{H}$ could not be separated from each other by gas chromatography by using the MIS software package and together were considered summed feature 2 .

c Summed feature 4 consists of $16: 1 \omega 7 \mathrm{t}$ and 15:0 iso $2 \mathrm{OH}$ (not separated by the MIS).

${ }^{d}$ Summed feature 7 consists of 18:1 $\omega 7 \mathrm{c}, 18: 1 \omega 9 \mathrm{t}$, and 18:1 $\omega 12 \mathrm{t}$ (not separated by the MIS).

rods with $\mathrm{G}+\mathrm{C}$ contents ranging from 41 to $42 \mathrm{~mol} \%$. In a previous study, strain NF3 ${ }^{\mathrm{T}}$ was assigned to the genus Pseudoalteromonas on the basis of its Gram reaction, cell morphology, motility, reactions in biochemical tests, fatty acid composition, protein pattern, and $\mathrm{G}+\mathrm{C}$ content (8). This strain is similar to NF2, NF13, NF14, and EN10. These strains were strictly aerobic (negative in the oxidation-fermentation test) and oxidase positive and required $\mathrm{Na}^{+}$ions $(17 \mathrm{mM})$ for growth. The sodium ion requirement of the Antarctic strains was lower than that of other Pseudoalteromonas species, for which the

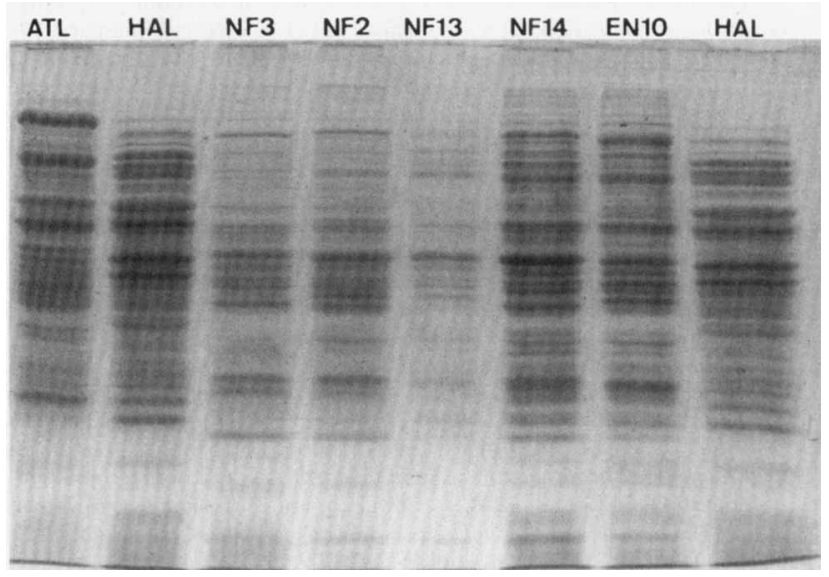

FIG. 2. Profiles of proteins after PAGE of $P$. atlantica IAM 14164 (ATL), P. haloplanktis CECT $4188^{\mathrm{T}}$ (HAL), and strains NF2, NF3 ${ }^{\mathrm{T}}$, NF13, NF14, and EN10. optimal $\mathrm{Na}^{+}$concentrations range from 125 to $600 \mathrm{mM}$ (17). 16S rRNA gene sequence analysis placed strain $\mathrm{NF}^{\mathrm{T}}$ on the Pseudoalteromonas branch, confirming the previous assignment to the genus on the basis of phenotypic traits (8). The closest relative observed after the sequence analysis was $P$. haloplanktis subsp. haloplanktis, with $99 \%$ sequence similarity (Fig. 3). DNA-DNA hybridization results showed that the five Antarctic bacterial isolates constituted a homogeneous genomic group with $\Delta T_{m}$ levels always less than $2.4^{\circ} \mathrm{C}$, levels

TABLE 4. Levels of DNA relatedness among strains

\begin{tabular}{|c|c|c|c|}
\hline \multirow[b]{2}{*}{ Strain } & \multirow{2}{*}{$\begin{array}{l}\text { \% DNA binding with } \\
\text { P. haloplanktis } \\
\text { CECT } 4188^{\mathrm{T} a}\end{array}$} & \multicolumn{2}{|c|}{$\Delta T_{m}\left({ }^{\circ} \mathrm{C}\right)$ with $^{b}:$} \\
\hline & & $\begin{array}{l}\text { P. atlantica } \\
\text { IAM } 12927^{\mathrm{T}}\end{array}$ & $\mathrm{NF}^{\mathrm{T}}$ \\
\hline P. atlantica IAM $12927^{\mathrm{T}}$ & & 0 & 10.5 \\
\hline P. atlantica IAM 14161 & & 4.5 & \\
\hline P. atlantica IAM 14162 & & 4.6 & \\
\hline P. atlantica IAM 14163 & & 2.9 & \\
\hline P. atlantica IAM 14165 & & 3.6 & \\
\hline P. carragenovora IAM $12662^{\mathrm{T}}$ & & 7.6 & 11.9 \\
\hline P. haloplanktis CECT $4188^{\mathrm{T}}$ & 100 & 8.6 & \\
\hline $\mathrm{NF}^{\mathrm{T}}$ & 21 & 8.0 & 0 \\
\hline NF2 & 22 & 7.3 & 0.9 \\
\hline NF13 & 22 & 7.2 & 2.4 \\
\hline NF14 & 22 & 7.1 & 1.8 \\
\hline EN10 & 20 & 7.3 & 2.0 \\
\hline
\end{tabular}

${ }^{a}$ Levels of DNA-DNA hybridization were determined spectrophotometrically by the method of De Ley et al. (11).

${ }^{b}$ DNA-DNA similarity values were determined by the quantitative bacterial dot filter method as described by Tjernberg et al. (46). 


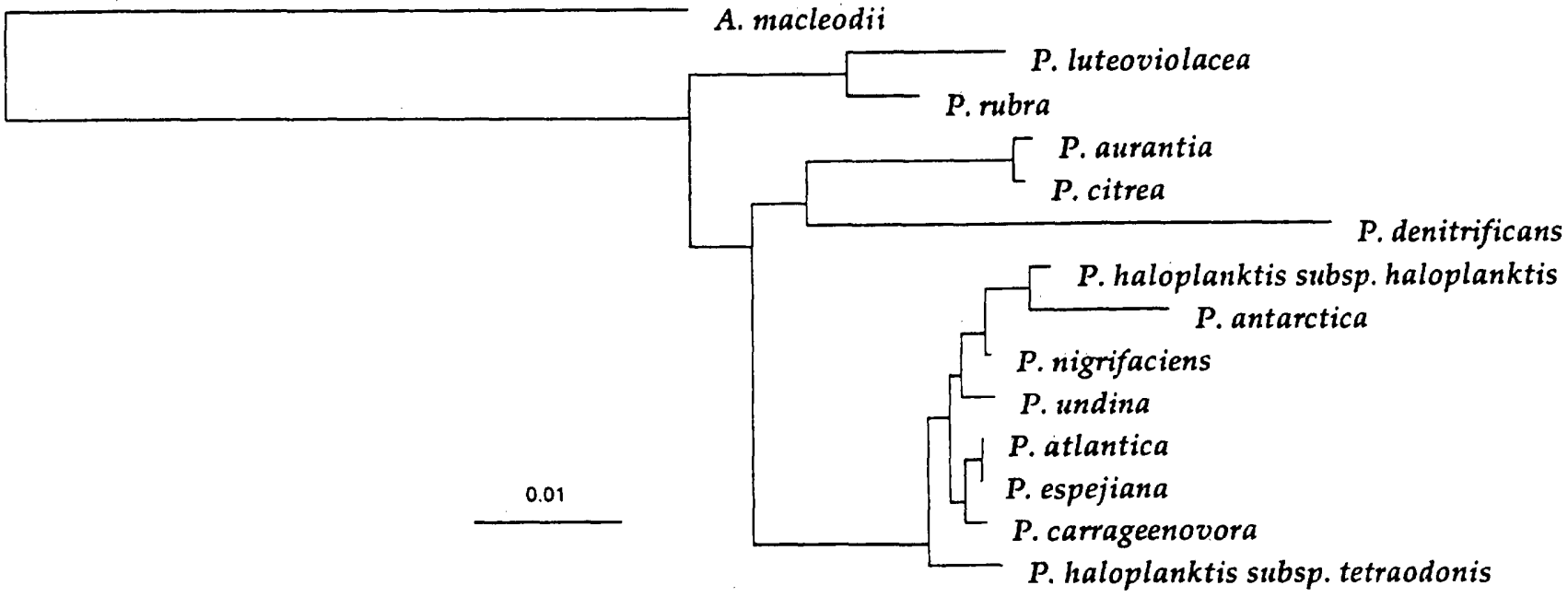

FIG. 3. Phylogenetic tree showing the positions of $P$. antarctica and related organisms based on 16S rRNA sequence similarity data.

that could be correlated with levels of similarity of $80 \%$ or more (26). However, the levels of similarity between these strains and the type strain of $P$. haloplanktis subsp. haloplanktis ranged from 20 to $22 \%$, values distant enough from the species most closely related phylogenetically to be classified as members of a new species (47). Although the level of 16S rRNA similarity with the closest relative ( $99 \%$ ) is high for two species (43), the observed value is still low for the average level of similarity within the genus (15). The results of SDS-PAGE and fatty acid analysis confirmed that the group of five Antarctic isolates is quite homogeneous. The patterns were also similar but not identical to the patterns observed for $P$. haloplanktis CECT $4188^{\mathrm{T}}\left(=\right.$ ATCC $\left.14393^{\mathrm{T}}\right)$. All of the results indicated that the Antarctic isolates really constitute a genomically isolated, phenotypically identifiable new Pseudoalteromonas species for which a set of differential phenotypic tests can be defined (Table 2): We propose the name Pseudoalteromonas antarctica sp. nov. for the bacterial strains isolated from Antarctic coastal areas; strain NF3 (= CECT4664) is the type strain of this species.

Description of Pseudoalteromonas antarctica sp. nov. Pseudoalteromonas antarctica (ant.arc'ti.ca. L. fem. adj. antarctica, of the Antarctic environment, where the organism was isolated). Gram-negative, strictly aerobic, rod-shaped cells that are 0.3 to $0.9 \mu \mathrm{m}$ wide and 1 to $3 \mu \mathrm{m}$ long when the organism is grown in TSB. Cells occur singly or in pairs, and after $24 \mathrm{~h}$ of incubation in liquid medium filaments $10 \mu \mathrm{m}$ long are observed. Microcysts or endospores are not formed. Cells are motile by means of a single polar flagellum. Peritrichous flagellation is not observed when the organism is cultivated on solid media. Cells grow at 4 to $30^{\circ} \mathrm{C}$. Colonies on TSA are beige, smooth, convex, and mucoid with entire edges and grow to diameters of 1 to $2 \mathrm{~mm}$ in 5 days at $15^{\circ} \mathrm{C}$ and $5 \mathrm{~mm}$ or more when colonies are incubated for longer periods of time (10 to 14 days). A low level of sodium ions, $17 \mathrm{mM} \mathrm{NaCl}$, is required for growth. Growth factors are not required. Positive in oxidase, catalase, alkaline phosphatase, esterase (C4), esterase lipase (C8), leucine arylamidase, cystine arylamidase, valine arylamidase, acid phosphatase, and naphthol-AS-BI-phosphohydrolase tests. Positive for hydrolysis of gelatin and casein. Negative for nitrate reduction, indole production, and arginine dihydrolase activity. Acid is produced from glucose, maltose, starch, galactose, and mannitol. Grows on D-glucose, D-mannitol, and maltose. Malate, sorbitol, and $m$-hydroxybenzoate are not used as sole carbon sources. The main cellular fatty acids are 16:1 $\omega 7 \mathrm{c}, 16: 0$, $17: 1 \omega 8 \mathrm{c}$, and 12:0 $3 \mathrm{OH}$. Isolated from muddy soils and sediments collected from Antarctic coastal areas. The $\mathrm{G}+\mathrm{C}$ content of the DNA is 41 to $42 \mathrm{~mol} \%$. The type strain is strain CECT 4664. Strains NF3 ${ }^{\mathrm{T}}$, NF2, NF13, NF14, and EN10 have been deposited in the Spanish Type Culture Collection as strains CECT $4664^{\mathrm{T}}$, CECT 4665, CECT 4666, CECT 4667, and CECT 4668 , respectively.

\section{ACKNOWLEDGMENTS}

This work was supported by grants ANT 779/89-E and ANT 95/0107 from CICYT (Spain).

We thank Josefina Castellví for providing Antarctic samples. We gratefully acknowledge the assistance of F. Garcia (Departament d'Agricultura, Ramaderia i Pesca, Generalitat de Catalunya, Spain) with the fatty acid analysis. We thank the Microscopy Service of Barcelona University (Spain) for technical assistance. We acknowledge the LMG Culture Collection (Laboratorium voor Microbiologie, Universiteit Gent, Ghent, Belgium) for performing the hybridization analysis. We thank Akagawa-Matsushita (University of Occupational and Environmental Health, Kitakyushu, Japan) for supplying bacterial strains. We also thank Robin Rycroft for revising the manuscript.

\section{REFERENCES}

1. Akagawa-Matsushita, M., Y. Koga, and K. Yamasato. 1993. DNA relatedness among nonpigmented species of Alteromonas and synonymy of Altero monas haloplanktis (Zobell and Upham 1944) Reicheit and Baumann 1973 and Alteromonas tetraodonis Simidu et al. 1990. Int. J. Syst. Bacteriol. 43. and Alterom 503 .

2. Akagawa-Matsushita, M., M. Matsuo, Y. Koga, and K. Yamasato. 1992 Alteromonas atlantica sp. nov. and Alteromonas carragenovora sp. nov., bacteria that decompose algal polysaccharides. Int. J. Syst. Bacteriol. 42:621627.

3. Bauer, A. N., W. M. M. Kirby, J. C. Sherry, and M. Turck. 1966. Antibiotic susceptibility testing by a standardized single disc method. Am. J. Clin. Pathol. 45:493-496.

4. Baumann, L., P. Baumann, M. Mandel, and R. D. Allen. 1972. Taxonomy of aerobic marine eubacteria. J. Bacteriol. 110:402-429.

5. Baumann, P., and L. Baumann. 1981. The marine Gram-negative eubacteria genera Photobacterium, Beneckea, Alteromonas, Pseudomonas, and Alcaligenes, p. 1302-1330. In M. P. Starr, H. Stolp, H. G. Trüper, A. Balows, and H. G. Schlegel (ed.), The prokaryotes. A handbook on habitats, isolation and identification of bacteria, vol. 2. Springer-Verlag A. G., Berlin, Germany.

6. Baumann, P., L. Baumann, R. D. Bowditch, and B. Beaman. 1984. Taxonomy of Alteromonas: $A$. nigrifaciens sp. nov., nom. rev.; $A$. macleodii; and $A$ haloplanktis. Int. J. Syst. Bacteriol. 34:145-149.

7. Baumann, P., M. J. Gauthier, and L. Baumann. 1984. Genus Alteromonas Baumann, Baumann, Mandel, and Allen, 1972, 418, p. 343-352. In N. R. Krieg and J. G. Holt (ed.), Bergey's manual of systematic bacteriology, vol. 1. The Williams \& Wilkins Co., Baltimore. 
8. Bozal, N., A. Manresa, J. Castellví, and J. Guinea. 1994. A new bacterial strain of Antarctica, Alteromonas sp. that produces a heteropolymer slime. Polar Biol. 14:561-567.

9. Chan, K. Y., L. Baumann, M. M. Gazza, and P. Baumann. 1978. Two new species of Alteromonas: Alteromonas espejiana and Alteromonas undina. Int. J. Syst. Bacteriol. 28:217-222.

10. Cowan, S. T., and K. J. Steel. 1974. Manual for the identification of medical bacteria, 2nd ed. Cambridge University Press, Cambridge, United Kingdom.

11. De Ley, J., H. Cattoir, and A. Reynaerts. 1970. The quantitative measurement of DNA hybridization from renaturation rates. Eur. J. Biochem. 12: 133-142.

12. Enger, O., H. Nygaard, M. Solberg, G. Schei, J. Nielsen, and I. Dundas. 1987. Characterization of Alteromonas denitrificans sp. nov. Int. J. Syst. Bacteriol. 37:416-421.

13. Felsenstein, J. 1982. Numerical methods for inferring phylogenetic trees. Q. Rev. Biol. 57:379-404.

14. Ferragut, C., and H. Leclerc. 1976. Etude comparative des méthodes de determination du $\mathrm{T}_{\mathrm{m}}$ de l'ADN bactérien. Ann. Microbiol. (Paris) 127:223235 .

15. Gauthier, G., M. Gauthier, and R. Christen. 1995. Phylogenetic analysis of the genera Alteromonas, Shewanella, and Moritella using genes coding for small-subunit rRNA sequences and division of the genus Alteromonas into two genera, Alteromonas (emended) and Pseudoalteromonas gen. nov., and proposal of twelve new species combinations. Int. J. Syst. Bacteriol. 45:755761

16. Gauthier, M. J. 1976. Alteromonas rubra sp. nov., a new marine antibioticproducing bacterium. Int. J. Syst. Bacteriol. 26:459-466.

17. Gauthier, M. J. 1977. Alteromonas citrea, a new gram-negative, yellow-pigmented species from seawater. Int. J. Syst. Bacteriol. 27:349-354.

18. Gauthier, M. J., and V. A. Breittmayer. 1979. A new antibiotic-producing bacterium from seawater: Alteromonas aurantia sp. nov. Int. J. Syst. Bacteriol. 29:366-372.

19. Gauthier, M. J. 1982. Validation of the name Alteromonas luteoviolacea. Int J. Syst. Bacteriol. 32:82-86.

20. Gauthier, M. J., and V. A. Breittmayer. 1992. The genera Alteromonas and Marinomonas, p. 3046-3084. In A. Balows, H. G. Trüper, M. Dworkin, W. Harder, and K. H. Schleifer (ed.), The prokaryotes, 2nd ed., vol. 3. SpringerVerlag, Berlin, Germany.

21. Hugh, R., and E. Leifson. 1953. The taxonomic significance of fermentative versus oxidative metabolism of carbohydrates by various gram-negative bacteria. J. Bacteriol, 66:24-26.

22. International Journal of Systematic Bacteriology. 1981. Validation of the publication of new names and new combinations previously effectively published outside the IJSB. List no. 6. Int. J. Syst. Bacteriol. 31:215-218.

23. Ivanova, E. P., E. A. Kiprianova, V. V. Mikhailov, G. F. Levanova, A. D. Garagulya, N. M. Gorshkova, N. Yumoto, and S. Yoshikawa. 1996. Characterization and identification of marine Alteromonas nigrifaciens strains and emendation of the description. Int. J. Syst. Bacteriol. 46:223-228.

24. Jeffries, C. D., D. F. Holtman, and D. G. Guse. 1957. Rapid method for determining the activity of microorganisms on nucleic acids. J. Bacteriol. 73:590.

25. Jensen, M. J., B. M. Tebo, P. Baumann, M. Mandel, and K. H. Nealson. 1980. Characterization of Alteromonas hanedai (sp. nov,), a nonfermentative luminous species of marine origin. Curr. Microbiol. 3:311-315.

26. Johnson, J. L. 1985. DNA reassociation and RNA hybridization of bacterial nucleic acids. Methods Microbiol. 28:33-74.

27. King, E. O., M. K. Ward, and D. E. Raney. 1954. Two simple media for the demonstration of pyocyanin and fluorescein. J. Lab. Clin. Med. 44:301.

28. Kodama, K., H. Shiozawa, and A. Ishi. 1993. Alteromonas rava sp. nov., a marine bacterium that produces a new antibiotic, thiomarinol. Annu. Rep. Sankyo Res. Lab. 45:131-136.
29. Kovács, N. 1956. Identification of Pseudomonas pyocyanea by the oxidase reaction. Nature (London) 178:703.

30. Lee, J. V., D. M. Gibson, and J. M. Shewan. 1977. A numerical taxonomic study of some pseudomonas-like marine bacteria. J. Gen. Microbiol. 98:439451.

31. Lelliot, R. A., E. Billing, and A. C. Hayward. 1966. A determinative scheme for the fluorescent plant pathogenic pseudomonads. J. Appl. Bacteriol. 29, $470-489$

32. Maidak, B. L., N. Larsen, M. J. MacCaughey, R. Overbeek, G. Olsen, K Fogel, J. Blandy, and C. R. Woese. 1995. The Ribosomal Database Project. Nucleic Acids Res. 22:3485-3487.

33. Marmur, J. 1961. A procedure for the isolation of deoxyribonucleic acids from microorganisms. J. Mol. Biol, 3:208-218.

34. Marmur, J., and P. Doty. 1962. Determination of the base composition of deoxyribonucleic acid from its thermal denaturation temperature. J. Mol. Biol. 5:109-118.

35. Owen, R. J., and L. R. Hill. 1979. The estimation of base compositions, base pairing and genome size of bacterial deoxyribonucleic acids, p. 217-296. In F. A. Skinner and D. W. Lovelock (ed.), Identification methods for microbiologists, 2nd ed. Academic Press, London, United Kingdom.

36. Owen, R. J., and D. Pitcher. 1985. Current methods for estimating DNA base composition and levels of DNA-DNA hybridization, p. 67-93. In M. Goodfellow and E. Minnikin (ed.), Chemical methods in bacterial systematics. Academic Press, London, United Kingdom.

37. Palleroni, N. J., and M. Doudoroff. 1972. Some properties and taxonomic subdivisions of the genus Pseudomonas. Annu. Rev. Phytopathol. 10:73-100.

38. Sambrook; J., E. F. Fritsch, and T. Maniatis. 1989. Molecular cloning: laboratory manual, 2nd ed. Cold Spring Harbor Laboratory Press, Cold Spring Harbor, N.Y.

39. Selin, Y. M., B. Harisch, and J. L. Johnson. 1983. Preparation of labeled rucleic acids (nick translation and iodination) for DNA homology and rRNA hybridization experiments. Curr. Microbiol. 8:127-132.

40. Sierra, G. 1957. A simple method for the detection of lipolytic activity of microorganisms and some observations on the influence of contact between cells and fatty substrates. Antonie van Leewenhoek 23:37-52.

41. Simidu, U., K. Kita-Tsukamoto, T. Yasumoto, and M. Yotsu. 1990. Taxonomy of four marine bacterial strains that produce tetrodotoxin. Int. J. Syst. Bacteriol. 40:331-336.

42. Springer, N., W. Ludwig, R. Amann, H. J. Schmidt, H. D. Gorth, and K. H. Schleifer. 1993. Occurrence of fragmented 16S rRNA in an obligate bacterial endosymbiont of Paramecium caudatum. Proc. Natl. Acad. Sci. USA 90: 9892-9895.

43. Stackebrandt, E, and B. M. Goebel. 1994. Taxonomic note: a place for DNA-DNA reassociation and 16S rRNA sequence analysis in the present species definition in bacteriology. Int. J. Syst. Bacteriol. 44:846-849.

44. Strunk, O., and W. Ludwig. Unpublished data.

45. Thornley, M. J. 1960. The differentiation of Pseudomonas from other gramnegative bacteria on the basis of arginine metabolism. J. Appl. Bacteriol. 23:37-52.

46. Tjernberg, I., E. Lindh, and J. Ursing. 1989. A quantitative bacterial method for DNA-DNA hybridization and its correlation to the hydroxyapatite method. Curr. Microbiol. 18:77-81.

47. Wayne, L. G., D. J. Brenner, R. R. Colwell, P. A. D. Grimont, O. Kandler, M. I. Krichevsky, L. H. Moore, W. E. C. Moore, R. G. E. Murray, E Stackebrandt, M. P. Starr, and H. G. Trüper. 1987. Report of the Ad Hoc Committee on Reconciliation of Approaches to Bacterial Systematics. Int. J Syst. Bacteriol. 37:463-464.

48. Weiner, R. M., V. E. Coyne, P. Brayton, P. West, and S. F. Raiken. 1988 Alteromonas colwelliana sp. nov., an isolate from oyster habitats. Int. J. Syst. Bacteriol. 38:240-244. 